\title{
BUDAYA MINANGKABAU DAN IMPLEMENTASI PADA MANAJEMEN RUMAH MAKAN PADANG DI YOGYAKARTA
}

\author{
Henny Welsa \\ henny_welsa@yahoo.com \\ Suharti \\ Latifah \\ Universitas Sarjanawiyata Tamansiswa
}

\begin{abstract}
The research was intended to identify the cultural factors that influenced entrepreneurship, business skills, and performance of Padang restaurant business in Yogyakarta Special Region. It is expected that the research will directly encourage entrepreneurship in Indonesia and provide a solution to the employment and unemployment rates in Indonesia and particularly in Yogyakarta. The research objects were Padang restaurants who already have a business license. The reason for choosing Yogyakarta as the setting was because Yogyakarta represents a student city and a tourist destination. Its population consists of diverse ethnic groups and $60 \%$ of the regional revenue comes from tourism where one of the tourism facilities is restaurant. Padang Restaurant has been developing rapidly in Yogyakarta area. The number of respondents were 50 Padang restaurant owners. The research instrument was a questionnaire and the data were analyzed by employing Partial Least Square (PLS). The research result shows that Minangkabau culture significantly affects the entrepreneurship, business capabilities, and business performance; whereas entrepreneurship does not significantly affect the capability of business to performance.
\end{abstract}

Key words: Minangkabau culture, entrepreneurship, business competence and business performance

\begin{abstract}
ABSTRAK
Pada dasarnya penelitian ini merupakan suatu studi untuk melihat faktor budaya yang mempengaruhi kewirausahaan, kemampuan usaha dan kinerja Usaha Rumah Makan Padang yang ada di Daerah Istimewa Yogyakarta. Diharapkan secara langsung akan mendorong kewirausahaaan di Indonesia dan merupakan solusi terhadap penyerapan tenaga kerja serta pengangguran di Indonesia dan khususnya di DIY. Adapun objek penelitian yang diteliti adalah Rumah Makan Padang yang telah memiliki surat izin usaha, Alasan memilih wilayah Daerah Istimewa Yogyakarta adalah karena Yogyakarta adalah kota pelajar dan wisata yang penduduknya terdiri dari beragam suku bangsa dan Pendapatan Asli Daerah Yogyakarta 60\% berasal dari Pariwisata dimana salah satu sarana pariwisata adalah Rumah Makan. Perkembangan Rumah Makan Padang cukup pesat didaerah IstimewaYogyakarta. Jumlah Sampling 50 responden pemilik restoran Padang dengan mengunakan kuisioner serta teknik analisis data menggunakan analisis Partial Least Square (PLS). Hasil penelitian menjelaskan bahwa Budaya Minangkabau berpengaruh signifikan terhadap kewirausahaan, kemampuan usaha, kinerja usaha, serta Kewirausahaan berpengaruh tidak signifikan terhadap kemampuan usaha berpengaruh signifikan terhadap kinerja usaha.
\end{abstract}

Kata kunci: budaya Minangkabau, kewirausahaan, kemampuan usaha dan kinerja usaha

\section{PENDAHULUAN}

Pada dasarnya penelitian ini merupakan suatu studi untuk melihat faktor budaya yang mempengaruhi kewirausahaan, kemampuan usaha dan kinerja Usaha Rumah
Makan Padang yang ada di Daerah Istimewa Yogyakarta Diharapkan secara langsung akan mendorong kewirausahaan di Indonesia dan merupakan solusi terhadap pe nyerapan tenaga kerja serta pengangguran 
di Indonesia dan khususnya di DIY. Alasan penelitian ini membahas tentang usaha rumah makan Padang adalah untuk dapat membantu pemerintah dalam mengatasi pengangguran. Kinerja Rumah Makan Padang dapat diketahui dengan menguji dan menganalisis faktor yang mempengaruhi Rumah Makan Padang. Dengan penelitian ini diharapkan dapat ditemukan langkah-langkah perubahan pada keadaan yang lebih baik. Memilih wilayah Daerah Istimewa Yogyakarta adalah karena Yogyakarta adalah kota pelajar dan wisata yang penduduknya terdiri dari beragam suku bangsa dan Pendapatan Asli Daerah Yogyakarta $60 \%$ berasal dari Pariwisata dimana salah satu sarana pariwisata adalah Rumah Makan. Perkembangan Rumah Makan Padang cukup pesat didaerah Istimewa Yogyakarta. Sabri (2013) dalam penelitiannya menjelaskan bahwa para wirausaha (entrepreneur) merupakan asset atau modal pembangunan yang harus dipelihara dan dikembangluaskan dalam masyarakat, khususnya masyarakat terdidik, sehingga pada gilirannya mampu ikut mendukung percepatan pembangunan negeri, di satu sisi dan mengurangi beban negara lain.

Wirausaha adalah kegiatan kegiatan pengembangan sumberdaya manusia yang dilatarbelakangi oleh kondisi sosial-budaya seperti terdapat pada masyarakat Minangkabau, khususnya dalam usaha Rumah Makan Padang. Kondisi geografis dan sosiologis ditopang dengan budaya Minangkabau, antara lain menumbuhkan nilai dan perilaku merantau sebagai ciri dan perilaku migrasi dan dalam aspek ekonomi memunculkan kewirausahaan yang tumbuh dalam lembaga Rumah Makan Padang. Kajian budaya memberikan isyarat bahwa eksistensi lembaga tersebut ternyata ditopang oleh kekuatan nilai budaya Minangkabau yang berhasil memberikan landasan nilai bagi tumbuhnya etos kerja dalam pengelolaan rumah makan tersebut. Berdasarkan uraian didepan, maka dapat disimpulkan bahwa jika dibandingkan dengan beberapa penelitian sebelumnya, maka penelitian ini menggunakan 5 (lima) indikator budaya Minangkabau yang mana pada penelitian Welsa (2009) mengungkapkan bahwa hanya menggunakan 3 indikator untuk mengukur variabel budaya dan delapan indikator jiwa kewirausahaan untuk mengukur variabel kewirausahaan, sepuluh indikator kemampuan usaha untuk mengukur variabel kemampuan usaha dan empat indikator kinerja usaha untuk mengukur variabel kinerja usaha Rumah Makan Padang.

Tujuan penelitian ini adalah untuk mengetahui apakah budaya masyarakat Minangkabau berpengaruh terhadap kewirausahaan, kemampuan usaha serta kinerja usaha pada Rumah Makan Padang di Yogyakarta.

\section{TINJAUAN TEORETIS \\ Budaya Minangkabau}

Unsur budaya yang universal dan sekaligus menjadi isi dari semua kebudayaan yang ada didunia ini menurut Kuntjaraningrat (1990) adalah sistim religi, sistim kemasyarakatan, sistim pengetahuan, bahasa kesenian, sistim mata pencaharian dan sistim teknologi peralatan. Ketujuh unsur kebudayan ini mencakup seluruh kebudayaan manusia dimanapun kombinasi dari ketujuh unsur ini pula yang menentukan nilai-nilai kehidupan dalam suatu masyarakat. Rante (2010) menjelaskan bahwa budaya lokal tidak memiliki dampak terhadap kinerja UKM agribisnis dibandingkan dengan budaya etnis yang lebih mengutamakan kepentingan adat dan kebersamaan. Sistim kemasyarakatan matrilineal yang dipilih nenek moyang masyarakat Minangkabau kendati langka namun diterima oleh masyarakat Minangkabau hingga saat ini. Sistim pengetahuan yang bertumpu pada ajaran "Alam takambang jadi guru" menjadi alasan utama bagi pendidikan yang logis dan rasional, serta mendorong kearah kehidupan yang serasi secara alami dan sadar lingkungan. Mata pecaharian 
orang Minang saat ini menurut penelitian hampir $60 \%$ memiliki mata pencaharian sebagai wirausaha. Orang Minang mengatakan adat basandikan syarak, syarak bersandikan kitabullah, jadi dari sisi religi jelas masyarakat minangkabau beragama Islam, apabila ada orang Minang yang tidak beragama Islam, dia tidak mungkin disebut orang Minangkabau. Jadi jelas dari ketujuh unsur budaya yang dikemukakan oleh Koentjaraningrat (1990) sudah terpenuhi oleh budaya Minangkabau. Fauzan (2011) menjelaskan bahwa religiusitas atau rasa keberagamaan walaupun tidak dominan, tetapi cukup mewarnai perilaku etis dalam bisnis rumah makan Padang. Pemilik rumah makan Padang mayoritas adalah pemeluk agama Islam, sehingga muatan-muatan ajaran Islam cukup mewarnai aktivitas bisnisnya.

Lukas (2004) mengemukakan bahwa fungsi perekonomian orang Tionghoa adalah kontekstual dengan fungsi eksitensi orang Tionghoa di Indonesia. Dalam fungsi tersebut, ada unsur positif dan negatif yang muncul, antara orang Tionghoa dan Bumi Putera. Indikator yang digunakan dalam penelitian ini adalah: (a) Agama, (b) Budaya Merantau, (c) Pendidikan Dalam Keluarga, (d) pekerjaan, (e) kemasyarakatan.

\section{Kewirausahaan}

Alfianto (2012) mengatakan bahwa untuk memulai usaha baru dan manfaat menjadi wirausaha terdapat beberapa paradigma sukses dalam berbisnis yang berkembang di masyarakat diantaranya keharusan menjadi seorang pebisnis. Nurseto (2004) menjelaskan bahwa salah satu pola penciptaan wirausaha baru yang tangguh dapat dilakukan pada tataran penciptaan iklim yang mampu menanamkan budaya wirausaha. Purhantara (2013) menjelaskan bahwa penguasaan nilai-nilai kewirausahaan, di antara karyawan lulusan SMA dan SMK tidak terjadi perbedaan yang signifikan. Rata-rata mereka kurang memiliki jiwa kewirausahaan atau tidak dapat mengimplementasikannya di pekerjaannya.
Menurut Dalimunthe (2002), ada delapan indikator yang harus dimiliki seorang enterpreneur yaitu (1) visi, (2) perencanaan, (3) motivasi, (4) Inovasi, (5) peluang, (6) percaya diri, (7) resiko, (8) adaptasi.

\section{Kemampuan Usaha}

Kemampuan usaha menurut peneliti berdasarkan penelitian Dalimunthe (2002) yang harus dimiliki Rumah Makan Padang ada 9 (sembilan) variabel yaitu: (1) Bahan baku, (2) Tenaga kerja, (3) Teknologi, (4) Kualitas produk, (5) Harga, (6) Variasi produk, (7) Jangkauan pasar, (8) Kemudahan membeli, (9) Ketersediaan modal. Menurut Suci (2009), dengan tingginya orientasi kewirausahan yang dimiliki akan lebih mudah untuk meningkatkan kemampuan manajemen, sedangkan menurut Fithri dan Sari (2012) indikator kompetensi kewirausahaan memiliki mental yang kuat, mampu bergaul dan, kemampuan untuk menganalisis masalah, kemampuan untuk mengarahkan karyawan, kemampuan untuk memberikan motivasi kepada karyawannya, dan kemampuan untuk berkomunikasi baik secara tertulis maupun secara verbal dengan baik.

\section{Kinerja Usaha}

Kinerja usaha adalah output dari berbagai faktor di atas yang oleh karenanya ukuran ini menjadi sangat penting untuk mengetahui tingkat adaptabilitas bisnis dengan lingkungannya. Kinerja organisasi juga dipengaruhi oleh kinerja individu yakni berkaitan dengan karakteristik individu, hal ini sejalan dengan penjelasan Dalimunthe (2002). Orientasi pasar berpengaruh positif dan signifikan terhadap profitabilitas. Menurut Sumantri et al. (2013) kinerja usaha dipengaruhi oleh karakteristik personal, kewirausahaan, lingkungan internal, dan lingkungan eksternal.

Beberapa penelitian telah dilakukan untuk mengetahui tentang pengaruh kewirausahaan kemampuan usaha serta kinerja usaha. Menurut penelitian Purnama (2011); dan Dalimunthe (2002) mengatakan 
bahwa kemampuan usaha berpengaruh terhadap keberhasilan usaha dibanding motivasi serta juga terhadap keberhasilan usaha sedangkan hasil penelitian Aprilianty (2013); Suharti dan Sirine (2011); Lestari dan Wijaya (2012) mengatakan bahwa potensi kepribadian, pengetahuan wirausaha, wirausaha dan lingkungan keluarga berpengaruh terhadap minat wirausaha, serta niat dan minat kewirausahaan

Berdasarkan penelitian Alfianto (2012) dan Sabri (2013) menyatakan manfaat menjadi wirausaha beberapa paradigma sukses dalam berbisnis yang berkembang di masyarakat diantaranya keharusan menjadi seorang pebisnis. serta kewirausahaan (entrepreneur) merupakan asset atau modal pembangunan yang harus dipelihara dan dikembang luaskan dalam masyarakat, khususnya masyarakat terdidik.

Penelitian Hadiyati (2011); dan Adam (2005) menyatakan kreativitas dan inovasi berpengaruh terhadap kewirausahaan dan "Respondents generally agree with the relevance of all factors associated with influencing business networks or joint venture business establishment. However, some factors are strongly significant for business networking, while others are not as strong".

Penelitian lainnya yaitu oleh Fauzan (2011); dan Darwis (2004) religiusitas atau rasa keberagamaan mewarnai perilaku dalam bisnis Rumah Makan Padang. Di dukung oleh kekuatan nilai-nilai yang bersumber dari sosial budaya daerah Minang yang dilandasi ajaran Islam.

Pada penelitian Setyawati (2013); Setiawan (2013); Andiningtyas dan Nugroho (2014); dan Wijaya (2008) menyatakan hubungan antara orientasi kewirausahaan terhadap orientasi pasar adalah positif sedangkan variabel orientasi pasar, budaya organisasi dan orientasi kewirausahaan berpengaruh secara bersama-sama terhadap kinerja usaha. Sikap berwirausaha, norma subjektif dan efikasi diri berpengaruh positif terhadap perilaku berwirausaha.

Penelitian dari Fithri dan Sari (2012); dan Nurseto (2004) indikator kompetensi kewirausahaan antara lain: memiliki mental yang kuat, mampu bergaul dan, kemampuan untuk menganalisis masalah, kemampuan untuk mengarahkan karyawan, kemampuan untuk memberikan motivasi kepada karyawannya, dan kemampuan untuk berkomunikasi baik secara tertulis maupun secara verbal dengan baik. Serta pola penciptaan wirausaha baru yang tangguh dapat dilakukan pada tataran penciptaan iklim yang mampu menanamkan budaya wirausaha.

Dalam Penelitian Reswanda (2011); Lestari dan Megawati (2015) dan Sultan (2015), kewirausahaan dapat meningkatkan kemampuan pembelajaran organisasi keunggulan daya saing berkelanjutan pada UMKM serta terdapat pengaruh karakteristik personal dan orientasi kewirausahaan terhadap kinerja UKM. Dan kompetensi wirausaha memiliki pengaruh terhadap strategi bisnis dan daya saing usaha kecil.

Pada penelitian Rante (2010); dan Purhantara (2013) mengatakan bahwa budaya lokal tidak memiliki dampak terhadap kinerja UKM. Budaya etnis yang lebih mengutamakan kepentingan adat dan kebersamaan. Penelitian penguasaan nilai-nilai kewirausahaan, tidak terjadi perbedaan yang signifikan, sedangkan Lukas (2004) dalam penelitiannya menyatakan bahwa fungsi perekonomian orang Tionghoa adalah kontekstual dengan fungsi eksitensi orang Tionghoa di Indonesia. Begitu juga Naim (1979) memyatakan yang tinggal di Sumatera Barat sama banyak dengan yang pergi merantau. Sebab, faktor dominan yang menyebabkan orang Minangkabau merantau adalah faktor ekonomi dan pendidikan.

\section{Hipotesis \\ Pengaruh Budaya Minangkabau dengan Kewirausahaan}

Unsur budaya yang universal dan sekaligus menjadi isi dari semua kebudayaan yang ada didunia ini menurut Koentjaraningrat (1990) adalah sistim religi, sistim kemasyarakatan, sistim pengetahuan, baha- 
sa kesenian, sistim mata pencaharian dan sistim teknologi peralatan. Ketujuh unsur kebudayan ini mencakup seluruh kebudayaan manusia dimanapun kombinasi dari ketujuh unsur ini pula yang menentukan nilai-nilai kehidupan dalam suatu masyarakat.

Mata pecaharian orang Minang saat ini menurut penelitian hampir $60 \%$ memiliki mata pencaharian sebagai wirausaha, sedangkan menurut Fauzan (2011) Religiusitas atau rasa keberagamaan walaupun tidak dominan, tetapi cukup mewarnai perilaku etis dalam bisnis rumah makan Padang. Pemilik rumah makan Padang mayoritas adalah pemeluk agama Islam, sehingga muatan-muatan ajaran Islam cukup mewarnai aktivitas bisnisnya. Darwis (2004) menyatakan bahwa Keberadaan Rumah Makan Padang didukung oleh kekuatan nilai-nilai yang bersumber dari sosial budaya daerah Minang yang dilandasi ajaran Islam. Begitu juga dengan Naim (1979) menyampaikan bahwa masyarakat minang yang tinggal di Sumatera Barat sama banyak dengan yang pergi merantau. Sebab, faktor dominan yang menyebabkan orang Minangkabau merantau adalah faktor ekonomi dan pendidikan.

Dengan demikian berdasarkan pernyataan tersebut diatas dapat dikatakan bahwa unsur-unsur budaya Minangkabau mewarnai aktifitas bisnis. Untuk itu penelitian ini mengajukan hipotesis sebagai berikut:

$\mathrm{H}_{1}$ : Budaya Minangkabau memiliki pengaruh signifikan terhadap Kewirausahaan

\section{Pengaruh Budaya Minangkabau terhadap Kemampuan Usaha}

Wirausaha adalah kegiatan-kegiatan pengembangan sumberdaya manusia yang dilatarbelakangi oleh kondisi sosial-budaya seperti terdapat pada masyarakat Minangkabau, khususnya dalam usaha Rumah Makan Padang. Kondisi geografis dan sosiologis ditopang dengan budaya Minangkabau, antara lain menumbuhkan nilai dan perilaku merantau sebagai ciri dan perilaku migrasi dan dalam aspek ekonomi memunculkan kewirausahaan yang tumbuh dalam lembaga Rumah Makan Padang. Kajian budaya memberikan isyarat bahwa eksistensi lembaga tersebut ternyata ditopang oleh kekuatan nilai budaya Minangkabau yang berhasil memberikan landasan nilai bagi tumbuhnya etos kerja dalam pengelolaan rumah makan tersebut pada penelitian Welsa (2009) budaya Minangkabau berpengaruh positive dan signifikan pada rumah makan padang yang ada di Yogyakarta dan Kemampuan usaha disini dalam artian Kemampuan (Capabilities) mengacu pada ketrampilan (skill) perusahaan dalam mengkoordinasikan sumber daya dan menempatkannya untuk penggunaan secara produktif.

Dengan demikian berdasarkan pernyataan tersebut diatas dapat dikatakan bahwa unsur-unsur budaya Minangkabau landasan etos kerja sehigga menigkatkan kemampuan dalam menjalankan usaha. Untuk itu penelitian ini mengajukan hipotesis sebagai berikut:

$\mathrm{H}_{2}$ : Budaya Minangkabau memiliki pengaruh signifikan terhadap kemampuan usaha.

\section{Pengaruh Budaya Minangkabau terhadap Kinerja}

Kinerja yang ada dipengaruhi oleh budaya yang dibentuk pada lingkungan budaya pengusaha ataupun karyawan Rumah Makan padang sesuai Konsep kehidupan yang disiapkan nenek moyang dari orang Minang untuk bekerja keras, bertujuan mencapai suatu kehidupan yang bahagia dan sejahtera dunia dan akhirat yang termasuk didalamnya adalah adanya kinerja pengelolaan usaha yang baik menurut Welsa (2009) sedangkan Kinerja usaha adalah output dari berbagai factor, karenanya ukuran ini menjadi sangat penting untuk mengetahui tingkat adaptabilitas bisnis dengan lingkungannya kinerja organisasi juga dipengaruhi oleh kinerja individu yakni berkaitan dengan karakteristik individu 
menurut Kumalaningrum (2012) sedangkan menurut Rante (2010) Budaya lokal tidak memiliki dampak terhadap kinerja UKM agribisnis. Budaya etnis lebih mengutamakan kepentingan adat dan kebersamaan.

Dengan demikian berdasarkan pernyataan tersebut diatas dapat dikatakan bahwa Kinerja yang ada dipengaruhi oleh budaya yang dibentuk pada lingkungan budaya pengusaha dalam menjalankan usaha. Untuk itu penelitian ini mengajukan hipotesis sebagai berikut:

$\mathrm{H}_{3}$ : Budaya Minangkabau memiliki pengaruh signifikan terhadap kinerja

\section{Pengaruh Kewirausahaan Terhadap Ke- mampuan Usaha}

Dengan tingginya orientasi kewirausahan yang dimiliki akan lebih mudah untuk meningkatkan kemampuan manajemen. Fithri dan Sari (2012) menyimpulkan bahwa kewirausahaan harus memiliki mental yang kuat, mampu bergaul dan, kemampuan untuk menganalisis masalah, kemampuan untuk mengarahkan karyawan, kemampuan untuk memberikan motivasi kepada karyawannya, dan kemampuan untuk berkomunikasi baik secara tertulis maupun secara verbal dengan baik. Disisi lain terkait dengan kewirausahaan menurut Dalimunthe (2002) Kewirausahaan mempunyai pengaruh langsung positif terhadap keberhasilan usaha dan kemampuan usaha berpengaruh langsung terhadap keberhasilan usaha pada usaha Tenun dan Bordir di Sumatera Utara dan sejalan dengan Penelitian dari Purnama (2011) yang mana hasil penelitiannya adalah kemampuan usaha berpengaruh terhadap keberhasilan usaha dibanding motivasi.

Berdasarkan penjelasan diatas dapat di simpulkan bahwa orientasi kewirausahaan yang dimiliki dapat meningkatkan kemampuan manajemen maka dibentuk hipotesis sebagai berikut:

$\mathrm{H}_{4}$ : Kewirausahaan memiliki pengaruh signifikan terhadap kemampuan usaha.

\section{Pengaruh Kewirausahaan terhadap kinerja} usaha

Usaha yang sukses dan mampu bertahan lama, akan banyak dipengaruhi oleh motivasi yang dimiliki pimpinan wirausaha, oleh karenanya, untuk menjadi wirausahawan yang berhasil diperlukan seseorang yang berbakat dan mempunyai motivasi untuk menciptakan sesuatu yang baru sesuai dengan keinginan. Motivasi merupakan semangat dan wawasan yang akan membuat seseorang bekerja keras untuk melakukan pembentukan ide atau gagasan baru, sehingga akan membuat kinerja usaha menjadi lebih menguntungkan dengan meningkatnya semangat untuk mengembangkan usaha dan dalam penelitiannya juga Dalimunthe (2002) menyatakan bahwa Kewirausahaan berpengaruh positive terhadap kinerja usaha industri tenun dan Bordir di Sumatera Utara serta sejalan dengan Setiawan (2013) dalam penelitianya menunjukkan bahwa variabel orientasi pasar, budaya organisasi dan orientasi kewirausahaan berpengaruh secara bersama-sama terhadap kinerja usaha. Begitu juga dalam Penelitian Lestari dan Megawati (2015) mengatakan bahawa terdapat pengaruh karakteristik personal dan orientasi kewirausahaan terhadap kinerja UKM. Berdasarkan penjelasan dari penelitian diatas dapat disimpulkan usaha yang sukses dipengaruhi motivasi dan akan meningkatkan kinerja usaha maka dibentuk hipotesis sebagai berikut:

$\mathrm{H}_{5}$ : Kewirausahaan memiliki pengaruh signifikan terhadap kinerja usaha

\section{METODE PENELITIAN}

Sebagaimana yang telah ditunjukkan dalam peta jalan atau alur penelitian bahwa penelitian ini terdiri atas beberapa tahap. Tahapan dari penelitian secara ringkas dapat terlihat pada tabel 1 di bawah ini:

\section{Tabel 1}

Tahapan dalam Penelitian

\begin{tabular}{ll}
\hline \hline Penelitian & Dampak budaya terhadap jiwa \\
& wirausaha, kemampuan usaha \\
& dan kinerja usaha.
\end{tabular}




\begin{tabular}{|c|c|}
\hline $\begin{array}{l}\text { Variabel } \\
\text { penelitian }\end{array}$ & $\begin{array}{l}\text { Variabel dependen: kemampuan } \\
\text { usaha dan kinerja usaha. } \\
\text { Variabel independen: budaya } \\
\text { minangkabau. } \\
\text { Variabel intervening: jiwa kewira- } \\
\text { usahaan. }\end{array}$ \\
\hline $\begin{array}{l}\text { Metoda } \\
\text { penelitian }\end{array}$ & $\begin{array}{l}\text { Metoda pengambilan data: } \\
\text { Kuesioner. } \\
\text { Populasi: Rumah Makan Padang } \\
\text { di Daerah Istimewa Yogyakarta. } \\
\text { Sampel: } 50 \text { buah RM Padang di } \\
\text { Daerah Istimewa Yogyakarta. } \\
\text { Metoda Sampel: proportional strati- } \\
\text { fied random sampling. } \\
\text { Uji instrument: uji validitas dan } \\
\text { reliabilitas. } \\
\text { Analisis data: PLS Analysis. }\end{array}$ \\
\hline $\begin{array}{l}\text { Tempat } \\
\text { penelitian }\end{array}$ & Daerah Istimewa Yogyakarta \\
\hline Luaran & $\begin{array}{l}\text { Model budaya Minangkabau yg } \\
\text { mempengruhi jiwa berwira- } \\
\text { usaha masyarakat Minang }\end{array}$ \\
\hline
\end{tabular}

Berikut merupakan penjabaran definisi operasional, indikator:

\section{Definisi dan Indikator}

Budaya Minangkabau adalah suatu konsep kehidupan yang disiapkan nenek moyang orang Minang untuk anak cucunya, yang bertujuan untuk mencapai suatu kehidupan yang bahagia dan sejahtera dunia dan akhirat. Budaya Minangkabau diukur berdasarkan indikator yang dikembangkan oleh Darwis (2004) menyatakan bahwa indikator budaya minangkabau terdiri dari pendidikan dan agama serta nilai kekeluargaan, sedangkan menurut Welsa (2009) indikator budaya Minangkabau terdiri dari agama, pendidikan dalam keluarga, serta merantau. Kewirausahaan yakni pengelompokan dari variabel-variabel yang menggambarkan sifat atau ciri yang dimiliki individu yang tercermin dalam pengelolaan dan pengembangan perusahaannya sendiri sekaligus menciptakan pekerjaan bagi orang lain. Dalam penelitian Welsa (2009) menjelaskan bahwa kewirausahaan di ukur dengan delapan indikator. (1) Visi, (2) perencananaan, (3) motivasi, (4) inovasi, (5) peluang, (6) percaya diri, (7) resiko serta, (8 ) adaptasi.

Kemampuan Usaha dalam menentukan kebijakan produksi, pemasaran dan keuangan mulai dari sebelum terjadi proses produksi hingga sesudah barang dimanfaatkan atau dipergunakan oleh konsumen. (Dalimunthe, 2002) indikator kemampuan usaha adalah (1) bahan baku, (2) tenaga kerja, (3) teknologi, (4) kualitas produk (5) harga, (6) variasi produk, (7) jangkauan pasar, (8) kemudahan membeli serta (9) ketersediaan modal. Kinerja usaha yang merupakan identifikasi keberhasilan usaha dari Rumah makan Padang di DIY diukur dengan tiga indikator yaitu (1) jumalah tenaga kerja, (2) produktivitas serta (3) pertumbuhan penjualan. Hal ini sesuai dengan penelitian Welsa (2009).

\section{ANALISIS DAN PEMBAHASAN Rumah Makan Padang}

Rumah Makan Padang yang dijadikan obyek studi utama dalam penelitian ini merupakan lembaga usaha swasta yang bergerak dalam penjualan jasa dan produk makanan yang khas daerah Minangkabau. Nama dari Rumah Makan Padang masih digunakan pada rumah makan yang ukuran sedang dan menengah, yang cikal bakalnya adalah lapau. Rumah Makan Padang memiliki ciri tersendiri dalam penataan ruangan, walaupun disesuaikan dengan kondisi ruangan, namun memiliki pola yang sama. Ruangan ditata menjadi tiga bagian yang memiliki fungsi khusus. Terdiri dari bagian belakang sebagai pusat produksi, bagian tengah sebagai pusat pemasaran dan kasir ada di bagian depan. Palung tempat menjajakan masakan yang siap dihidangkan.

Palung pada rumah makan besar biasanya ditempatkan dibagian tengah agak kesamping menghadap deretan kursi dan meja para tamu, untuk rumah makan menengah dan kecil, palung berada di depan dengan kasir. Situasi ini merupakan salah satu ciri dalam penataan tata ruang Rumah Makan Padang. 


\section{Deskripsi Variabel Penelitian}

Dalam penelitian ini digunakan analisis deskriptif dengan bantuan program statistik SPSS ver. 13 untuk mendiskripsikan variabel penelitian ini:

\section{Tabel 2}

\section{Deskripsi Variabel Budaya Minangkabau}

Variabel Budaya Minangkabau

\begin{tabular}{|c|c|c|c|}
\hline No. & Indikator Agama & Nilai & $\begin{array}{c}\text { Rata- } \\
\text { rata }\end{array}$ \\
\hline 1 & $\begin{array}{l}\text { Jenis makanan yang dipro- } \\
\text { duksi adalah dijamin halal }\end{array}$ & 231 & 4,62 \\
\hline 2 & $\begin{array}{l}\text { Mempertimbangkan } \\
\text { perekruitan karyawan masih } \\
\text { melihat faktor agama yang } \\
\text { dianut }\end{array}$ & 196 & 3,9 \\
\hline 3 & $\begin{array}{l}\text { Rumah makan mengadakan } \\
\text { pengajian antar karyawan }\end{array}$ & 194 & 3,9 \\
\hline 4 & $\begin{array}{l}\text { Rumah makan setiap tahun } \\
\text { mengeluarkan Zakat untuk }\end{array}$ & & \\
\hline & karyawan & 192 & 3,8 \\
\hline 5 & $\begin{array}{l}\text { Rumah makan setiap tahun } \\
\text { mengeluarkan Qurban } \\
\text { untuk karyawan }\end{array}$ & 153 & 3,1 \\
\hline 6 & $\begin{array}{l}\text { Pemilik rumah makan } \\
\text { melakukan pengajian } \\
\text { dengan pembagian }\end{array}$ & & \\
\hline & keuntungan & 163 & 3,3 \\
\hline & Jumlah & 1129 & 22,62 \\
\hline No. & Indikator Merantau & Nilai & $\begin{array}{c}\text { Rata- } \\
\text { rata }\end{array}$ \\
\hline 1 & $\begin{array}{l}\text { Pemilik rumah makan } \\
\text { merantau ke Yogyakarta } \\
\text { untuk memulai usaha }\end{array}$ & 193 & 3,9 \\
\hline 2 & $\begin{array}{l}\text { Pemilik rumah makan } \\
\text { merantau agar kehidupan } \\
\text { ekonomi keluarga lebih baik }\end{array}$ & 209 & 4,2 \\
\hline 3 & $\begin{array}{l}\text { Pemilik rumah makan } \\
\text { membawa keluarga dari } \\
\text { kampung halaman untuk } \\
\text { membantu mengelola rumah } \\
\text { makan }\end{array}$ & 153 & 3,1 \\
\hline 4 & $\begin{array}{l}\text { Pemilik rumah makan } \\
\text { sukses di rantau untuk } \\
\text { membantu pembangunan }\end{array}$ & & \\
\hline & kampung halaman & 163 & 3,26 \\
\hline & Jumlah & 718 & 14,46 \\
\hline No. & $\begin{array}{l}\text { Indikator Pendidikan } \\
\text { dalam Keluarga }\end{array}$ & Nilai & $\begin{array}{c}\text { Rata- } \\
\text { rata }\end{array}$ \\
\hline 1 & $\begin{array}{l}\text { Pemilik rumah makan } \\
\text { mendapatkan pendidikan } \\
\text { berwirausaha dalam }\end{array}$ & & \\
\hline & keluarga & 189 & 3,8 \\
\hline & Jumlah & 189 & 3,8 \\
\hline
\end{tabular}

\begin{tabular}{|c|c|c|c|}
\hline No. & $\begin{array}{l}\text { Indikator X1.4 } \\
\text { Pekerjaan }\end{array}$ & Nilai & $\begin{array}{c}\text { Rata- } \\
\text { rata }\end{array}$ \\
\hline 1 & $\begin{array}{l}\text { yakin pekerjaan } \\
\text { wirausaha adalah tujuan } \\
\text { utama }\end{array}$ & 207 & 4.1 \\
\hline 2 & $\begin{array}{l}\text { Yakin sebagai wirausaha } \\
\text { dapat menjamin masa depan }\end{array}$ & 195 & 3.9 \\
\hline & Jumlah & 402 & 8 \\
\hline No. & $\begin{array}{c}\text { Indikator X1.5 } \\
\text { Kemasyarakatan }\end{array}$ & Nilai & $\begin{array}{c}\text { Rata- } \\
\text { rata }\end{array}$ \\
\hline 1 & $\begin{array}{l}\text { Yakin wirausaha mampu } \\
\text { membantu mengatasi } \\
\text { penganguran } \\
\text { Wirausaha merupakan } \\
\text { suatu kebangaan }\end{array}$ & 209 & 4,2 \\
\hline & Jumlah & 406 & 8,1 \\
\hline
\end{tabular}

\section{Agama}

Indikator agama nilai tertinggi adalah pada pertanyaan Jenis makanan yang diproduksi adalah makanan yang dijamin halal sebesar 4,62 hal tersebut sudah sesuai dengan falsafah budaya minang kabau berasaskan falsafah Budaya Minangkabau Yaitu Adat bersandikan Syarak, Syarak bersandikan Kitabullah yaitu berdasarkan aturan-aturan agama Islam, sehingga apabila masyarakat yang beragama islam bepergian ke luar negri akan selalu mencari rumah makan padang karena yakin akan ke halalannya walau tanpa mendapatkan sertifikat halal dari MUI.

\section{Merantau}

Responden pergi merantau agar kehidupan ekonomi keluarga lebih baik hal tersebut terlihat dari persentase responden yang memberikan jawaban sangat setuju tujuan merantau ke Yogyakarta adalah untuk mendapatkan kehidupan yang lebih baik dibandingkan tetap tinggal dikampung dengan jumlah nilai rata2 sebesar 4,2.

\section{Pendidikan wirausaha dalam keluarga}

Pendidikan berwirausaha didapat dalam keluarga hal tersebut terlihat dari persentase responden yang memberikan jawaban sangat setuju mendapatkan pendidikan wirausaha dalam keluarga dengan jumlah sebanyak 50 responden atau sebesar $100 \%$. Dalam wawancara bebas dengan sebagian responden diperoleh informasi bah- 
wa sifat kewirausahaan dan keterampilan usaha sudah dengan sendirinya tertanam dalam pribadi mereka karena sejak dini dalam keluarga, mereka sudah terbiasa hidup dan berpikir dengan pola ulet, hemat Menabung atau telaten, sabar menunggu kesempatan lebih baik, tidak pernah putus asa dan menjadikan kegagalan sebagai pelajaran dalam memupuk pengalaman. Hal ini sesuai dengan hasil penelitian Lestari dan Wijaya (2012) yang menyatakan bahwa pendidikan kewirausahaan berpengaruh secara signifikan terhadap minat berwirausahaan.

\section{Pekerjaan}

Jawaban responden untuk indikator pekerjaan yang paling tinggi adalah mengatakan wirausaha adalah tujuan utama mereka jadi bukan untuk menjadi pegawai. Penelitian Suharti dan Sirine (2011) menyatakan bahwa faktor sosio demografi yaitu pekerjaan orangtua sebagai wirausahawan dan pengalaman berwirausaha mahasiswa, sikap (attitudes) yang meliputi autonomy/ authority, economic challenge, self realization, security $\mathcal{E}$ workload, serta faktor kontekstual yaitu academic support dan social support terbukti berpengaruh secara signifikan dan positif terhadap niat kewirausahaan.

\section{Kemasyarakatan}

Responden yakin dengan menjadi wirausaha dapat membantu pemerintah dalam mengentaskan kemiskinan dan ini terlihat dari nilai rata2 sebesar 4,2.

Tabel 3

\section{Deskripsi Variabel Kewirausahaan}

Variabel Kewirausahaan

\begin{tabular}{clrr}
\hline No. & \multicolumn{1}{c}{ Indikator Visi } & Nilai & $\begin{array}{c}\text { Rata- } \\
\text { rata }\end{array}$ \\
\hline 1 & $\begin{array}{l}\text { Pemilik rumah makan } \\
\text { memiliki visi dalam } \\
\text { menjalankan usaha }\end{array}$ & 217 & 4,3 \\
2 & $\begin{array}{l}\text { Pemilik rumah makan } \\
\text { melakukan segala } \\
\text { upaya agar visi } \\
\text { tersebut tercapai }\end{array}$ & 219 & $4,4$. \\
\hline & Jumlah & 436 & 4,3 \\
\hline
\end{tabular}

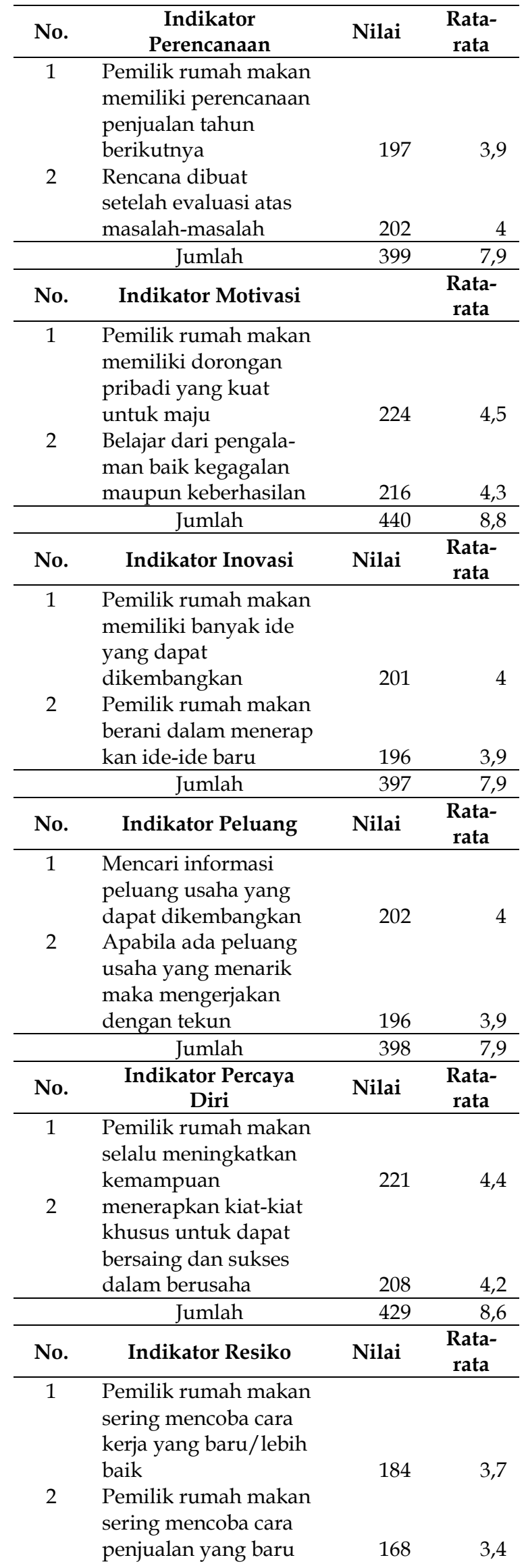




\begin{tabular}{rlrr}
3 & $\begin{array}{l}\text { Berani mengambil } \\
\text { resiko terhadap } \\
\text { keputusan yang } \\
\text { diambil }\end{array}$ & 192 & 344 \\
\hline No. & \multicolumn{1}{c}{ Jumlah } & Nilai & $\begin{array}{c}\text { Rata- } \\
\text { rata }\end{array}$ \\
\hline 1 & $\begin{array}{l}\text { Permintaan/ } \\
\text { keinginan pembeli } \\
\text { yang berbeda-beda } \\
\text { selalu dilayani } \\
\text { mempertahankan } \\
\text { resep lama dan me- } \\
\text { lakukan penyesuaian- } \\
\text { penyesuaian } \\
\text { Mampu menganti- } \\
\text { sipasi perubahan yang } \\
\text { terjadi di sekeliling } \\
\text { usaha }\end{array}$ & 203 & 4,1 \\
\hline$\quad$ Jumlah & 208 & 4,2 \\
\hline & & & \\
\hline
\end{tabular}

\section{Visi}

Pemilik rumah makan memiliki visi dalam menjalankan usaha dan melakukan segala upaya agar visi tersebut tercapai hal tersebut terlihat dari nilai rata-rata yang cukup tinggi sebesar 4,4.

Hasil penelitian menunjukan bahwa sebagian responden mempunyai visi yang jelas tentang bagaimana usahanya harus dan akan dikembangkan. Semakin tinggi pemahaman dan penerimaan visi organisasi semakin tinggi pula komitmen warga organisasi untuk bersama-sama mewujudkannya.

\section{Perencanaan}

Pemilik rumah makan memiliki perencanaan penjualan tahun berikutnya dan Rencana-rencana dibuat setelah melalui evaluasi yang mendalam atas masalahmasalah dan kesempatan yang ada hal tersebut terlihat dari nilai rata-rata yang cukup tinggi yaitu sebesar 4 . Dari jawaban responden terhadap indikator perencanaan dapat dilihat bahwa walaupun hanya mengelola Rumah Makan akan tetapi pemilik rumah makan telah memiliki perencanaan dan berupaya agar perencanaan tersebut dapat berjalan dengan baik dan mendapatkan hasil seperti yang diharapkan.

\section{Motivasi}

Pemilik usaha memiliki dorongan pribadi yang kuat untuk maju hal tersebut terlihat dari nilai rata-rata sebesar 4,5 Dari jawaban responden terhadap indikator motivasi terlihat bahwa pemilik rumah makan memiliki motivasi yang kuat untuk sukses dalam menjalankan usaha Rumah Makan Padang. Menurut Purnama (2011) kemampuan usaha lebih dominan pengaruhnya terhadap keberhasilan usaha dibandingkan dengan motivasi usaha.

\section{Inovasi}

Responden memiliki banyak ide yang dapat dikembangkan menjadi usaha yang menguntungkan hal tersebut terlihat dari nilai rata-rata tertinggi sebesar 4. Dari jawaban responden terhadap indikator inovasi menunjukan bahwa pemilik rumah makan memiliki banyak ide dan berusaha untuk menerapkan ide-ide tersebut untuk kelangsungan usaha agar tetap berjalan sesuai yang diharapkan.

Dari hasil penelitian Hadiyati (2011) menunjukkan bahwa kreativitas dan inovasi berpengaruh secara simultan terhadap kewirausahaan dengan variabel inovasi memiliki pengaruh yang lebih besar terhadap kewirausahaan.

\section{Peluang}

Responden sering mencari informasi peluang usaha yang dapat dikembangkan hal tersebut terlihat dari nilai tertinggi sebesar 4. Dari jawaban responden terhadap indikator peluang menunjukan bahwa pemilik Rumah Makan Padang selalu berusaha mencari peluang dan mengerjakan dengan tekun agar usaha dapat berjalan dengan baik.

\section{Percaya diri}

Responden selalu meningkatkan kemampuan hal tersebut terlihat dari nilai ratarata jawaban tertinggi responden yaitu dengan nilai 4,4. Dari jawaban responden terhadap indikator percaya diri didapat 
bahwa pemilik rumah makan memiliki kepercayaan diri yang cukup baik dan selalu berusaha meningkatkan kemampuan dan berusaha mencari kiat-kiat agar dapat bersaing dan berhasil dalam menjalankan usahanya.

\section{Pengambilan Resiko}

Responden berani mengambil resiko terhadap keputusan yang diambil dan memiliki tanggung jawab terhadap kelancaran usaha hal tersebut terlihat dari nilai rata-rata responden yang tertinngi 3,8. Dari jawaban responden atas pertanyaan dari indikator pengambilan resiko menunjukan bahwa pemilik Rumah Makan Padang berani mengambil suatu resiko dalam mencoba cara-cara baru dan bertanggung jawab atas keputusan tersebut. Penelitian ini mengungkapkan bahwa responden berani mengambil resiko berdasarkan pertimbangan yang masak dan perhitungan yang cermat.

\section{Adaptasi}

Permintaan/keinginan pembeli yang berbeda-beda selalu dilayani sesuai keinginan mereka hal tersebut terlihat dari nilai rata-rata tertinggi yaitu 4,2. Responden sering mempertahankan resep lama warisan keluarga dan melakukan penyesuaianpenyusuaian. Dari jawaban responden terhadap pertanyaan dari indikator adaptasi menunjukan bahwa pemilik Rumah Makan Padang mudah untuk beradaptasi dengan lingkungan usaha baik beradaptasi dengan rasa makanan dan keinginan-keinginan dari pelanggan selalu direspon dengan baik.

Dari hasil wawancara dapat disimpulkan bahwa responden mudah beradaptasi dengan lingkungannya akan tetapi identitas diri tidak akan pernah hilang, seperti pepatah berikut: Dima bumi dipijak, di sinan langik dijunjung $D i$ ma nagari diunyi, disinan adat dipakai. (Dimana bumi dipijak, disana langit dijunjung. Dimana negeri didiami, disana adat dipakai Darwis (2004). Maksud pepatah tersebut bahwa nilai-nilai budaya minang dapat dilaksanakan dimana saja, asal pandai menyesuaikan diri dengan masyarakat yang digauli. Menyuruh orang supaya bisa menyesuaikan diri dengan masyarakat di mana ia berada.

\section{Tabel 4}

\section{Deskripsi Variabel Kemampuan Usaha}

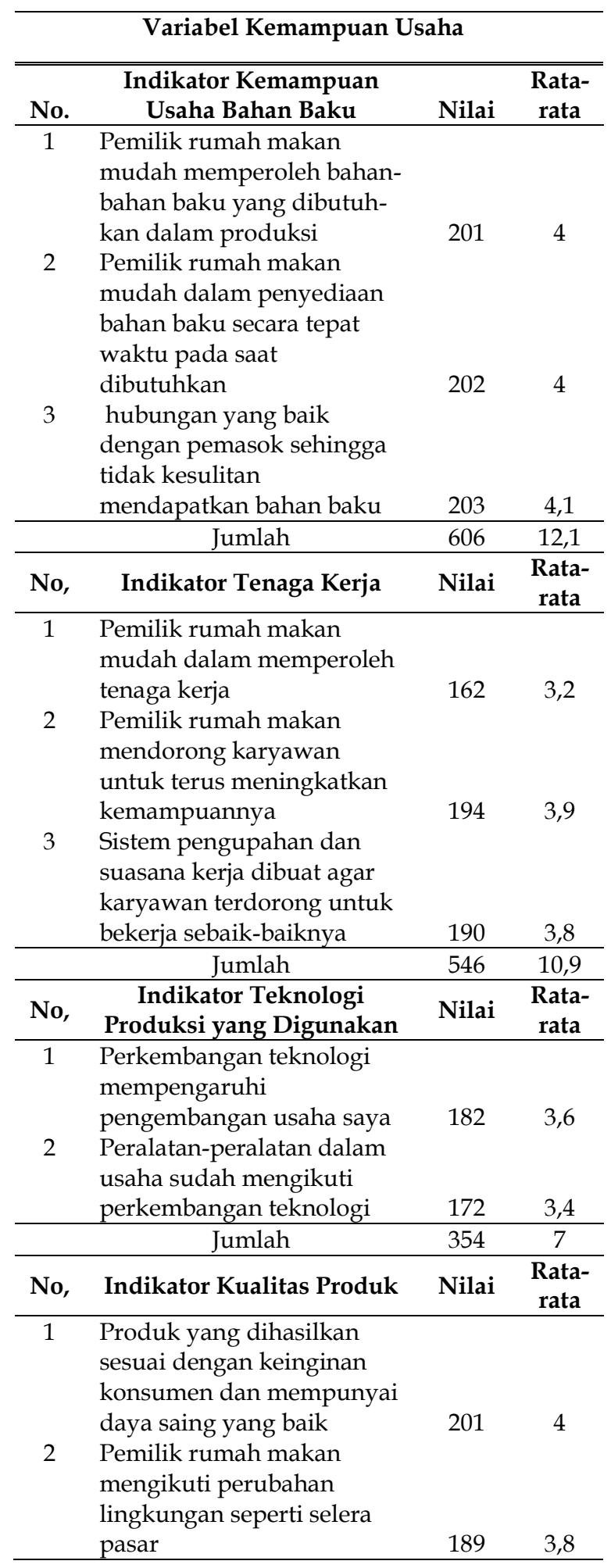




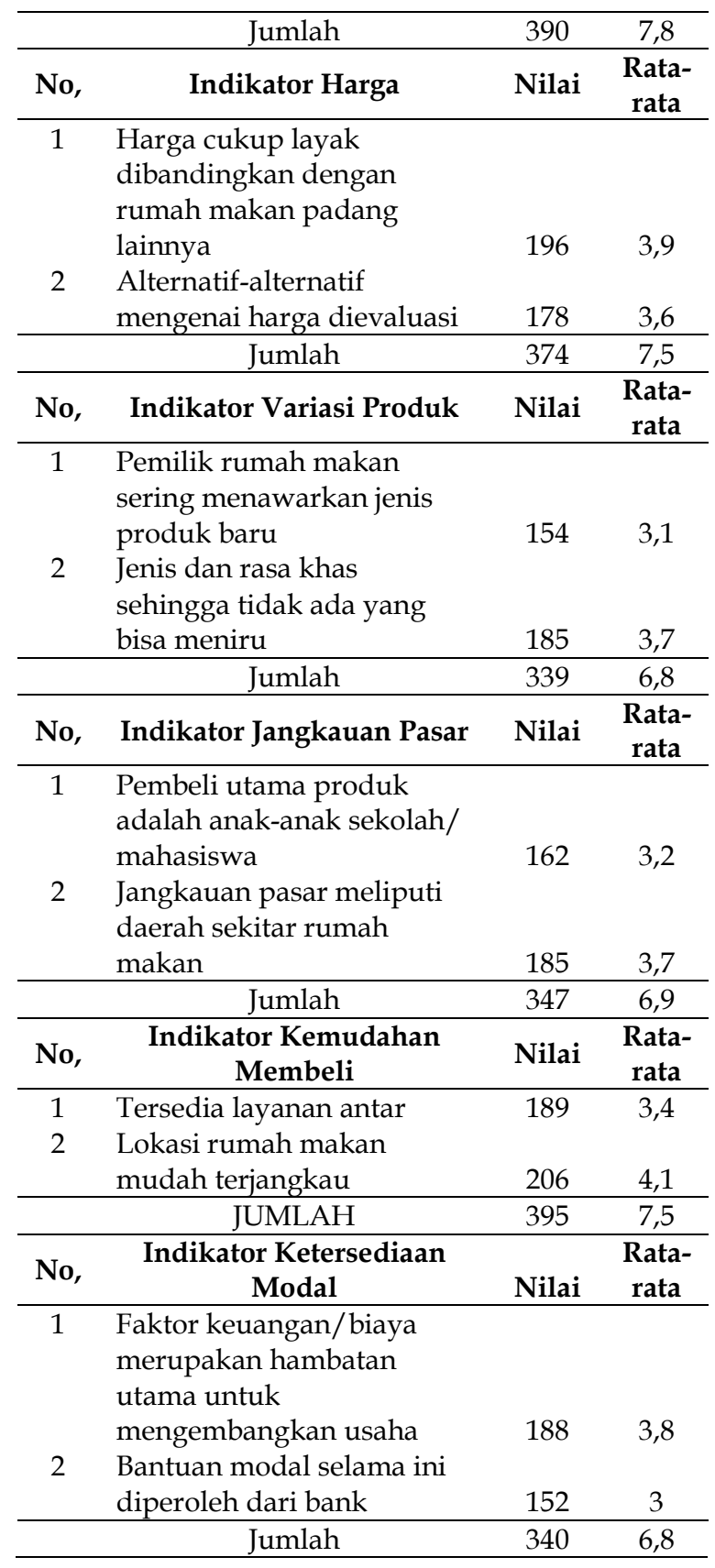

\section{Kemampuan Menyediakan Bahan Baku}

Responden mampu memperoleh bahanbahan baku yang dibutuhkan dalam produksi, memiliki hubungan yang baik dengan pemasok sehingga tidak kesulitan mendapatkan bahan baku hal tersebut terlihat dari nilai rata-rata yang sama pada semua pertanyaan terhadap bahan baku yaitu 4 .

\section{Tenaga Kerja}

Mudah dalam memperoleh tenaga kerja dan Selalu mendorong karyawan untuk terus meningkatkan kemampuannya terlihat sebagai nilai rata-rata tertinggi yaitu sesar 3,9, Dari jawaban responden menunjukan bahwa pemilik Rumah Makan cukup mudah dalam memperoleh karyawan dan selalu mendorong karyawan untuk terus meningkatkan kemampuannya dan kerja dengan suasana kekeluargaan agar karyawan dapat bekerja sebaik-baiknya.

\section{Bentuk Teknologi Produksi yang Di- gunakan}

Perkembangan teknologi mempengaruhi pengembangan usaha hal tersebut terlihat dari nilai rata-rata 3,6, Dari jawaban responden menunjukan bahwa pemilik Rumah Makan Padang sudah mengikuti perkembangan teknologi sebagai alat produksi dan teknologi tersebut cukup mempengaruhi perkembangan teknologi untuk dapat mempermudah dalam proses produksi.

\section{Kualitas Produk}

Produk yang dihasilkan sesuai dengan keinginan konsumen dan mempunyai daya saing yang baik hal tersebut terlihat dari nilai rata-rata tertinggi yaitu sebesar 4, Dari jawaban responden menunjukan bahwa pemilik Rumah Makan Padang selalu menjaga kualitas produk dan selalu menyesuaikan dengan selera konsumen misalnya rasa makanan tidak terlalu pedas dan asin,

\section{Harga}

Harga cukup bersaing dibandingkan dengan Rumah makan padang lainnya hal tersebut nilai tertinggi yaitu 3,9, Dari jawaban responden menunjukan bahwa harga relatif bersaing karena pasar sasaran utama usaha ini adalah pelajar dan mahasiswa yang keuanganya terbatas sehingga harga ini memang cukup mempengaruhi dalam kelangsungan usaha, Perubahan harga akan dievaluasi apabila terjadi kenaikan harga dari bahan baku.

\section{Variasi Produk}

Jenis dan rasa khas sehingga tidak ada yang bisa meniru hal tersebut terlihat 
sebagai nilai tertinggi yaitu sebesar 3,7, Dari jawaban responden menunjukan bahwa pemilik Rumah Makan Padang selalu menawarkan jenis makanan baru dengan memiliki kekhasan rasa agar dapat bersaing dengan Rumah Makan Padang lainnya.

\section{Jangkauan Pasar}

Pembeli utama produk adalah anakanak sekolah/mahasiswa hal tersebut terlihat nilai tertinggi yaitu sebesar 3,7, Jangkauan pasar meliputi Daerah sekitar Rumah makan hal tersebut Dari jawaban responden menunjukan bahwa pelangan Rumah Makan Padang adalah Pelajar dan mahasiswa terutama pelajar dan mahasiswa yang berasal dari Sumatra yang bertempat tinggal disekitar Rumah Makan oleh karena itu biasanya Rumah Makan Padang selalu mengambil lokasi mendekati kampus.

\section{Kemudahan Membeli}

Lokasi mudah terjangkau hal tersebut terlihat nilai rata-rata tertinngi yaitu sebesar 4,1, Dari jawaban responden menujukan bahwa mereka setuju inovasi layanan yaitu layanan antar walau belun terlaksana dengan baik hanya untuk anak-anak sekitar lokasi rumah makan atau Karyawan kantor yang sudah menjadi langganan Rumah makan, Pemilik rumah makan mencari lokasi yang mudah terjangkau pasar, karena pasar potensial adalah mahasiswa dan pelajar sehingga sebahagian besar Pemilik Rumah Makan selalu mencari lokasi di sekitar kampus.

\section{Ketersediaan Modal}

Faktor keuangan/biaya merupakan hambatan utama untuk mengembangkan usaha hal tersebut terlihat rata-rata tertinngi yaitu sebesar 3,8 Dari jawaban responden menunjukan bahwa pemilik Rumah Makan Padang menjawab bahwa permodalan adalah menjadi hambatan utama dalam mengembangkan usahanya dan salah satu alternatif menyelesaikannya yaitu dengan meminjam modal melalui jasa perbankan.
Tabel 5

Deskripsi Variabel Kinerja Usaha

Variabel Kinerja Usaha

\begin{tabular}{|c|c|c|c|}
\hline No. & $\begin{array}{c}\text { Indikator Jumlah } \\
\text { Tenaga Kerja } \\
\text { Relatif }\end{array}$ & Nilai & $\begin{array}{c}\text { Rata- } \\
\text { rata }\end{array}$ \\
\hline 1 & $\begin{array}{l}\text { Jumlah tenaga kerja } \\
\text { sudah sesuai } \\
\text { dengan kebutuhan }\end{array}$ & 207 & 4,1 \\
\hline 2 & $\begin{array}{l}\text { Membagi tugas } \\
\text { kepada karyawan } \\
\text { sesuai kemampuan } \\
\text { masing-masing }\end{array}$ & 203 & 4,1 \\
\hline & Jumlah & 410 & 8,2 \\
\hline No. & $\begin{array}{c}\text { Indikator } \\
\text { Produktivitas } \\
\text { Tenaga Kerja }\end{array}$ & Nilai & $\begin{array}{c}\text { Rata- } \\
\text { rata }\end{array}$ \\
\hline 1 & $\begin{array}{l}\text { Secara umum } \\
\text { merasa puas dengan } \\
\text { kemampuan } \\
\text { karyawan }\end{array}$ & 188 & 3,8 \\
\hline & Jumlah & 188 & 3,8 \\
\hline No. & $\begin{array}{c}\text { Indikator } \\
\text { Pertumbuhan } \\
\text { Penjualan }\end{array}$ & Nilai & $\begin{array}{c}\text { Rata- } \\
\text { rata }\end{array}$ \\
\hline 1 & $\begin{array}{l}\text { Pertumbuhan } \\
\text { penjualan tiga tahun } \\
\text { terakhir relatif } \\
\text { meningkat }\end{array}$ & 182 & 3,6 \\
\hline 2 & $\begin{array}{l}\text { Tiga tahun terakhir } \\
\text { ini laba bersih } \\
\text { rumah makan } \\
\text { pertahun relatif } \\
\text { meningkat }\end{array}$ & 190 & 3,8 \\
\hline & Jumlah & 372 & 7,4 \\
\hline
\end{tabular}

\section{Jumlah Tenaga Kerja}

Jumlah tenaga kerja sudah sesuai dengan kebutuhan, kemampuan dan keahlian masing-masing hal tersebut terlihat nilai rata-rata yang sama yaitu sebesar 4 .

\section{Produktivitas Tenaga Kerja}

Secara umum responden merasa puas dengan kinerja karyawan hal tersebut terlihat nilai rata-rata sebesar 3,8 .

\section{Pertumbuhan Penjualan}

Pertumbuhan penjualan tiga tahun terakhir relatif meningkat hal tersebut terlihat dari nilai rata-rata sebesar 3,8. 


\section{Hasil Pengujian Hipotesis Penelitian}

Hasil Pengujian hipotesis di atas maka dapat dilihat pada Tabel 6 berikut:

Tabel 6

Result for inner Loadings variabel laten

\begin{tabular}{lcccc}
\hline Arah Konstruk & $\begin{array}{c}\text { Weig } \\
\boldsymbol{h t}\end{array}$ & $\mathbf{t}_{\text {Hitung }}$ & $\mathbf{t}_{\text {Tabel }}$ & $\begin{array}{c}\text { Ketera } \\
\text { ngan }\end{array}$ \\
\hline $\begin{array}{l}\text { Budaya } \rightarrow \\
\text { kewirausahaan }\end{array}$ & 0,823 & 13,813 & 1,6602 & Signifikan \\
\hline $\begin{array}{l}\text { Budaya } \rightarrow \\
\text { Kinerja Usaha }\end{array}$ & 0,470 & 4,017 & 1,6602 & Signifikan \\
\hline $\begin{array}{l}\text { Budaya } \rightarrow \\
\text { kemampuan }\end{array}$ & 0,330 & 1910 & 1,6602 & Signifikan \\
\hline $\begin{array}{l}\text { Kewirausahaan } \\
\rightarrow \text { kemampuan }\end{array}$ & 0,385 & 1,370 & 1,6602 & $\begin{array}{c}\text { Tidak } \\
\text { Signifikan }\end{array}$ \\
\hline $\begin{array}{l}\text { Kewirausahaan } \\
\rightarrow \text { kinerja }\end{array}$ & 0,385 & 1,765 & 1,6602 & Signifikan \\
\hline
\end{tabular}

Pengujian Hipotesis 1: Budaya Minangkabau memiliki pengaruh signifikan terhadap kewirausahaan

Berdasarkan uji PLS juga dapat diketahui bahwa budaya minangkabau berpengaruh signifikan terhadap kewirausahaan karena nilai $t_{\text {hitung }}$ lebih besar dari $t_{\text {tabel }}$ sehingga $\mathrm{H}_{4}$ diterima, Budaya Minangkabau berpengaruh terhadap kewirausahaan dengan weight sebesar 0,823 dan bertanda positif,

Pengujian Hipotesis 2: Budaya Minang Kabau memiliki pengaruh signifikan terhadap kinerja usaha

Berdasarkan uji PLS juga dapat diketahui bahwa kewirausahaan berpengaruh signifikan terhadap kinerja usaha karena nilai $t_{\text {hitung }}$ lebih besar dari $t_{\text {tabel }}$ sehingga $\mathrm{H}_{2}$ diterima, Budaya Minangkabau berpengaruh terhadap kinerja usaha dengan weight sebesar 0,470 dan bertanda positif.

Pengujian Hipotesis 3: Budaya Minangkabau memiliki pengaruh signifikan terhadap kemampuan usaha

Berdasarkan uji PLS juga dapat diketahui bahwa budaya minangkabau berpengaruh signifikan terhadap kemampuan usaha karena nilai $t_{\text {hitung }}$ lebih besar dari tabel sehingga $\mathrm{H}_{6}$ ditolak, Budaya Minangkabau berpengaruh terhadap kemampuan usaha dengan weight sebesar 0,330 dan bertanda positif.

Pengujian Hipotesis 4: kewirausahaan memiliki pengaruh signifikan terhadap kemampuan usaha

Berdasarkan uji PLS juga dapat di ketahui bahwa kewirausahaan berpengaruh tidak signifikan terhadap kemampuan usaha karena nilai $t_{\text {hitung }}$ kecil dari $t_{\text {tabel }}$ sehingga $\mathrm{H}_{6}$ ditolak, Kewirausahaan berpengaruh tidak signifikan terhadap kemampuanusaha dengan weight sebesar 0,385 dan bertanda positif.

Pengujian Hipotesis 4: kewirausahaan memiliki pengaruh signifikan terhadap kinerja usaha

Berdasarkan uji PLS juga dapat diketahui bahwa kewirausahaan berpengaruh signifikan terhadap kinerja usaha karena nilai $t_{\text {hitung }}$ lebih besar dari $t_{\text {tabel }}$ sehingga $\mathrm{H}_{6}$ diterima, Kewirausahaan berpengaruh terhadap kinerja usaha dengan weight sebesar 0,385 dan bertanda positif.

\section{Hubungan masing-masing variabel dengan indikator}

Hubungan antara masing-masing variabel dengan semua indikatornya dapat dilihat dalam tabel 7 di bawah ini:

\section{VariabeL Budaya Minangkabau}

Tabel 7

Result for outer loadings Budaya Minangkabau

\begin{tabular}{|c|c|c|c|}
\hline $\begin{array}{l}\text { Indikator } \\
\text { Manifest }\end{array}$ & $\begin{array}{l}\text { Original } \\
\text { Estimate }\end{array}$ & $\begin{array}{c}\mathrm{T} \\
\text { Statistic } \\
\end{array}$ & Keterangan \\
\hline Agama & 0,643 & 4,199 & Signifikan \\
\hline Merantau & 0,031 & 0,114 & $\begin{array}{c}\text { Tidak } \\
\text { Signifikan }\end{array}$ \\
\hline Pekerjaan & 0,843 & 12,814 & Signifikan \\
\hline kemasyarakatan & 0,611 & 3,726 & Signifikan \\
\hline
\end{tabular}

Berdasarkan Tabel 7 didapatkan nilai loading factor bernilai 0,643 untuk Agama, 0,031untuk Merantau, 0,843 untuk pekerjaan, 0,611 yang berada diatas 0,5 menunjukkan signifikan karena nilai $\mathrm{t}$ agama 
4,199, merantau 0,114, pekerjaan 12,814 dan kemasyarakatan 3,726 berada diatas $\mathrm{t}$ tabel $=$ 1,6602 .

Kecuali untuk indikator merantau yang tidak signifikan nilai merantau tidak signifikan dari jawaban deskriptif menunjukan untuk merantau pemilik rumah makan sudah tidak lagi membawa sanak saudara untuk membantu mengelola rumah makan akan tetapi sudah mengunakan tenagakerja di lingkungan sekitar.

Tabel 8

Result for outer loadings Kewirausahaan

\begin{tabular}{llll}
$\begin{array}{l}\text { Indikator } \\
\text { Manifest }\end{array}$ & $\begin{array}{l}\text { Original } \\
\text { Estimate }\end{array}$ & $\begin{array}{l}\text { T } \\
\text { Statistic }\end{array}$ & Keterangan \\
\hline Visi & 0,627 & 6,674 & Signifikan \\
Motivasi & 0,806 & 11,326 & Signifikan \\
Inovasi & 0,847 & 15,434 & Signifikan \\
Peluang & 0,744 & 9,360 & Signifikan \\
Percaya diri & 0,782 & 13,731 & Signifikan \\
Pengambilan & 0,802 & 13,565 & Signifikan \\
resiko & 0,745 & 11,655 & Signifikan \\
Adaptasi & & & \\
\hline
\end{tabular}

Berdasarkan Tabel 8 didapatkan nilai loading factor bernilai 0,627 untuk Visi, 0,806, Perencanaan, 0,847, Motivasi, 0,744 , Inovasi, 0,782 , Peluang, 0,802, Percaya Diri dan 0,745 untuk Pengambilan Resiko yang berada diatas 0,5 menunjukkan signifikan karena nilai $\mathrm{t}$ Visi $=3,150, \mathrm{t}$ Perencanaan $=4,086, \mathrm{t}$ Motivasi $=13,856, \mathrm{t}$ Inovasi $=16,454, \mathrm{t}$ Peluang $=14,228, \mathrm{t}$ Percaya Diri $=2,916$ dan $\mathrm{t}$ Pengambilan Resiko $=3,091$ berada diatas $t$ tabel $=1,6602$.

\section{Variabel Laten Kemampuan Usaha}

Tabel 9

Result for outer loadings Kemampuan Usaha

\begin{tabular}{lccc}
\hline \hline $\begin{array}{c}\text { Indikator } \\
\text { Manifest }\end{array}$ & $\begin{array}{c}\text { Original } \\
\text { Estimate }\end{array}$ & $\begin{array}{c}\text { T } \\
\text { Statistic }\end{array}$ & Keterangan \\
\hline Bahan baku & 0,705 & 4,830 & Signifikan \\
Tenaga kerja & 0,791 & 6,165 & Signifikan \\
Harga & 0,818 & 6,679 & Signifikan \\
Variasi & 0,760 & 5,110 & Signifikan \\
Produk & 0,570 & 3,211 & Signifikan \\
Jangkauan & 0,605 & 3,407 & Signifikan \\
Pasar & & & \\
\hline
\end{tabular}

Kemudahan

Membeli

Berdasarkan Tabel 9 didapatkan nilai loading factor bernilai 0,705 untuk bahan baku Yang Digunakan, 0,791 untuk tenaga kerja yang digunakan,untuk Harga, 0,818 untuk Variasi Produk, 0,760 untuk Jangkauan Pasar, dan 0570 untuk Kemudahan membeli adalah 0,605, yang berada diatas 0,5 menunjukkan signifikan karena nilai $t$ bahan baku Yang Digunakan $=4,30$, tenaga kerja $=$ $6,165 \mathrm{t}$ Harga $=6,679, \mathrm{t}$ Variasi Produk $=$ 5,110, t Jangkauan Pasar $=3,211$, dan $\mathrm{t}$ Kemudahan Membeli $=3,407$ berada diatas $t$ tabel $=1,6602$,

\section{Variabel Kinerja Usaha}

Tabel 10

Result for outer loadings Kinerja Usaha

\begin{tabular}{lccc}
\hline \multicolumn{1}{c}{ Indikator Manifest } & $\begin{array}{c}\text { Original } \\
\text { Estimate }\end{array}$ & $\begin{array}{c}\text { T } \\
\text { Statistic }\end{array}$ & Keterangan \\
\cline { 1 - 2 } Jumlah Tenaga Kerja & & & \\
Produktivitas & 0,863 & 14,510 & Signifikan \\
Tenaga Kerja & 0,596 & 3,047 & Signifikan \\
Pertumbuhan & 0,876 & 15,153 & Signifikan \\
Penjualan & & & \\
\hline
\end{tabular}

Tabel 10 didapatkan nilai loading factor bernilai 0,863 untuk Jumlah tenaga kerja, 0,596 untuk produktivitas tenaga Kerja, 0,876 untuk pertumbuhan penjualan yang berada diatas 0,5 menunjukkan signifikan karena nilai $\mathrm{t}$ Jumlah tenaga kerja $=14,510, \mathrm{t}$ produktivitas tenaga Kerja $=3,047$, t pertumbuhan penjualan $=15,153$, berada diatas $\mathrm{t}$ tabel $=1,6602$.

Pengaruh Budaya terhadap Kewirausahaan

Hasil analisa PLS membuktikan bahwa Budaya Minang memiliki pengaruh signifikan terhadap Kewirausahaan, Analisis hasil penelitian mengenai pengaruh variabel Budaya Minangkabau terhadap kewirausahaan, dapat diuraikan sebagai berikut:

Rata-rata responden mendeskripsikan indikator maupun variabel Budaya Minangkabau kuat, Budaya Minang seperti yang 
telah diuraikan terdahulu, bahwa disusun berdasarkan dan berpedoman kepada ketentuan-ketentuan dari alam, Ketentuanketentuan tersebut adalah kekal selama alam itu masih ada dan ketentuan-ketentuan itu adalah kekal dalam perobahan-perobahan yang kekal pula, Yang kekal sejati dalam adat itulah yang "tidak lapuak dek hujan, tidak lakang dek paneh" (tidak lapuk oleh hujan, tidak kekeringan oleh panas), Kekekalan adat itu dalam perobahan-perobahan dan kekekalan perubahan-perubahan itu sendiri terlihat dalam pepatah Minangkabau, seperti: "Sakali aia gadang, sakali tapian baraliah, (Sekali air bah, sekali tepian berpindah), Maksud pepatah ini menyatakan, walaupun air bah itu akan selalu terjadi dan berakibat tepian akan beralih-alih, namun dalam segala perubahan dan peralihan itu sungai akan tetap sungai, Mungkin sungainya menjadi lebih besar dan tepiannya beralih Darwis (2004), Pengelolaan Rumah Makan Padang dan pengembangan sumber daya manusianya, terlihat mengaktualisasikan nilai tradisi kekeluargaan yang berpedoman kepada adat dan agama, Seperti pepatah mengata- kan "adat bersendikan syara', syara' bersendikan Kitabullah", Mengenai dasardasar agama dalam keberadaan Rumah Makan Padang, terlihat dari peraturan dan pembinaan agama Islam, Pada prinsipnya hal-hal yang dilarang agama tidak boleh dilaksanakan, Terbukti jika karyawan melakukan kesalahan dalam pekerjaan hanya dinasehati dan ditegur, Akan tetapi jika melanggar ajaran agama, akan diberi sanksi berat yakni dikeluarkan, Pentingnya ajaran Islam adalah untuk membentuk pribadi yang jujur, bertanggung jawab, dan berbuat positif, sehingga pengawasan di Rumah Makan Padang tak perlu dilakukan dengan ketat, karena masing-masing karyawan telah menjaga dirinya sendiri, Pengawasan melekat ditingkatkan menjadi pengawasan malaikat.

Pengawasan melekat ini tampak kaitannya dengan faktor nilai budaya, Nilai budaya yang kuat adalah yang bersumber dari keagamaan, sehingga dapat memper- kuat waskat (pengawasan melekat) internal, yang tumbuh atas kesadaran bahwa dalam dirinya selalu ada yang mengawasi dalam menjalankan pekerjaannya yaitu Tuhan Yang Maha Esa, Keyakinan seperti ini dalam suasana pembinaan sumber daya manusia pada Rumah Makan Padang mendapat pembinaan, Dampaknya dapat membentuk lingkungan dan suasana kerja sebagai kekuatan eksternal dalam pengawasan melekat (waskat) dan kekuatan nilai keagamaan yang membentuk kekuatan internal, sehingga pengawasan tersebut fungsional, lebih dari itu bertujuan untuk kepentingan bersama.

Norma bisnis dalam usaha Rumah Makan Padang ini tidak tertulis secara formal akan tetapi tumbuh secara turun temurun dan berkembang sesuai dengan perkembangan yang ada dan memiliki kekuatan adaptif dengan unsur budaya lokal di mana usaha ini didirikan, Berdasarkan kenyataan tersebut, terlihat bahwa keberadaan Rumah Makan Padang ditopang oleh kekuatan nilai-nilai yang bersumber dari sosial budaya daerah Minangkabau yang memiliki kekuatan transformasi ke arah prinsip-prinsip manajemen perusahaan modern, Kondisi ini merupakan kekuatan kultural yang memungkinkan perusahaan ini memiliki kekuatan kompetetif.

Untuk Indikator dan variabel Kewirausahaan didiskripsikan responden tinggi ini dapat dilihat bahwa Semangat wirausaha yang harus dimiliki pimpinan suatu usaha adalah yang bervisi, yang dapat menyesuaikan perusahaan terhadap situasi yang terus berubah-ubah karena berorientasi ke depan, memiliki motivasi yang tinggi, percaya diri, dan dapat fleksibel terhadap situasi dan kondisi serta memiliki perencanaan dalam menjalankan usahanya.

\section{Budaya Minangkabau Memiliki Pengaruh Signifikan terhadap Kinerja}

Budaya Minangkabau berpengaruh signifikan terhadap kinerja usaha artinya kinerja yang ada dipengaruhi oleh budaya yang dibentuk pada lingkungan budaya 
pengusaha ataupun karyawan Rumah Makan padang, Konsep kehidupan yang disiapkan nenek moyang dari orang Minang untuk bekerja keras, bertujuan mencapai suatu kehidupan yang bahagia dan sejahtera dunia dan akhirat yang termasuk didalamnya adalah adanya kinerja pengelolaan usaha yang baik, Dalam Manajemen Rumah Makan padang dilakukan pembinaan rohani, pembinaan rohani tersebut bukan saja terhadap para karyawannya, akan tetapi juga terhadap keluarga karyawan, Pengajian juga dilakukan terhadap anak-anak dan istri karyawan, Dari sinilah melahirkan rasa kekeluargaan yang kental yang dibina dengan nilai-nilai keagamaan, sedangkan pada perusahaan lain belum banyak atau belum tentu dikembangkan, Ternyata disadari bahwa pengawasan melekat yang memiliki makna sebagai "pengawasan malaikat" yang memiliki kekuatan ampuh sebagai penguat pengawasan melekat yang sekarang sedang dikembangkan dalam sistem manajemen.

\section{Budaya Minangkabau Memiliki Pengaruh Signifikan terhadap Kemampuan Usaha}

Budaya Minangkabau berpengaruh signifikan terhadap kemampuan usaha, Hal ini dapat dilihat bahwa masyarakat Minangkabau sebagian besar mempunyai pendidikan berwirausaha yang diperoleh dari keluarga, Dengan demikian ilmu atau pendidikan yang mereka peroleh mampu mengelola atau menerapkan pada usaha yang mereka jalani salah satunya mengelola Rumah Makan.

Budaya Minang ternyata memiliki pengaruh terhadap kemampuan usaha, Kemampuan usaha disini dalam artian Kemampuan (Capabilities) mengacu pada ketrampilan (skill) perusahaan dalam mengkoordinasikan sumber daya dan menempatkannya untuk penggunaan secara produktif, Kemampuan usaha mempunyai peranan yang besar dalam menciptakan kinerja.

Kewirausahaan memiliki pengaruh tidak signifikan terhadap Kemampuan Usaha
Temuan dari analisis hasil penelitian pengaruh terhadap variabel kewirausahaan terhadap kemampuan usaha dan dapat diuraikan sebagai berikut:

Kewirausahaan berpengaruh tidak signifikan terhadap kemampuan usaha, Pada kemampuan usaha terlihat nilai terendah adalah pada permasalahan permodalan sehingga membuat dalam berwirausaha akan terjadi hambatan untuk meningkatkan kemampuan usahanya walau demikian.

Hal ini dapat dilihat bahwa masyarakat Minangkabau memiliki visi dalam menjalankan usahanya, di mana visi dalam berwiraswasta memiliki kandungan gambaran yang baik untuk masa depan maupun masa kini, Dengan visi tersebut, seseorang memiliki kemampuan untuk mencapai tujuan yang ingin dicapai untuk masa depan, oleh karena itu seorang wirausaha harus bervisi dalam suatu organisasi agar dapat mendukung gerakan masa depan.

Kemampuan usaha dilihat dari unsur kemampuan menyediakan bahan baku sangat menunjang kesiapan usaha untuk menghasilkan produk (output) yang berupa barang dan jasa, Seperti yang ditemukan pada penelitian ini bahwa sebagian besar pengusaha rumah makan Padang mampu memperoleh bahan-bahan baku yang dibutuhkan dalam produksi dan mudah dalam penyediaan bahan baku ketika dibutuhkan secara tepat waktu pada saat dibutuhkan, Jika hal ini terus berjalan dengan baik maka proses produksi atau dalam hal ini proses usaha bisnis rumah makan Padang akan berjalan dengan lancar, Terlebih lagi sebagian besar pemilik rumah makan Padang telah memiliki hubungan yang baik dengan pemasok sehingga tidak kesulitan mendapatkan bahan baku.

Kemampuan usaha dilihat dari unsur tenaga kerja sangat diperlukan untuk perkembangan jalannya usaha tersebut, Seperti pada penelitian ini ditemukan bahwa pengusaha rumah makan menyatakan sangat mudah dalam memperoleh tenaga kerja, Tenaga kerja yang diperoleh biasanya 
berasal dari keluarga sendiri atau teman sekampung halaman, Kemampuan usaha yang mengacu dalam mengkoordinasikan sumber daya harus digunakan secara produktif, Hal ini dibuktikan oleh Pemilik rumah makan Padang yang berasal dari suku Minangkabau selalu mendorong karyawannya untuk terus meningkatkan kemampuannya, oleh karena itu kemampuan dari unsur tenaga kerja adalah strategi yang sangat penting terhadap kontribusi kelanjutan keunggulan kompetitif, Begitu halnya dengan system pengupahan dan suasana kerja untuk tenaga kerja, sebagian besar pemilik memberikan dorongan kepada karyawan untuk bekerja sebaik-baiknya.

Kemampuan usaha dilihat dari unsur teknologi sangat mempengaruhi pengembangan usaha, Seperti yang ditemukan dalam penelitian ini bahwa Pemilik rumah makan Padang sebagian besar menyatakan setuju atas pernyataan bahwa perkembangan teknologi mempengaruhi pengembangan usaha, Melihat sekarang persaingan bisnis terutama rumah makan lebih padat dengan layanan berteknologi, maka harus diimbangi dengan penggunaan teknologi yang canggih pula, Semakin tinggi kemampuan usaha tersebut dalam menggunakan teknologi, maka semakin meningkat pula pola pertumbuhan penjualan usaha, Hal ini dapat terjadi bila penggunaan teknologi dilakukan secara efektif yaitu menggunakannya, mengadaptasi, mengubah atau menciptakan teknologi dalam pengembangan proses usaha, Dalam hal ini Pemilik rumah makan Padang sudah menggunakan peralatanperalatan usaha yang mengikuti perkembangan teknologi.

Kemampuan usaha dilihat dari unsur kualitas produk penelitian menemukan bahwa pemilik rumah makan selalu mengikuti perubahan lingkungan seperti selera pasar, Memahami perilaku konsumen dan mengenal pelanggan bukan masalah yang sederhana, Para pelanggan mungkin menyatakan kebutuhan dan keinginan mereka namun bertindak sebaliknya, Hal ini kemungkinan pelanggan tidak memahami motivasi mereka yang lebih dalam, Untuk memahami motivasi pelanggan maka perusahaan harus mempelajari keinginan pelanggan dengan harapan dapat memberikan petunjuk bagi pengembangan produk dan harga, Temuan penelitian menunjukkan bahwa produk yang dihasilkan rumah makan Padang tersebut sebagian besar telah sesuai dengan keinginan konsumen dan mempunyai daya saing yang baik.

Penetapan harga yang diputuskan oleh pemilik rumah makan Padang sudah cukup layak bila dibandingkan dengan Rumah makan padang lainnya dan alternatifalternatif mengenai harga selalu dievaluasi, Penetapan harga menjadi hal yang sangat sensitif bagi seorang wirausahawan, Jika sudah yakin dengan target pasarnya, maka seorang wirausahawan harus pede memberi harga yang harus diimbangi jaminan kualitas produk yang bagus, Harga makanan Padang selain unsur yang penting dalam menentukan pangsa pasar dan keuntungan perusahaan, juga digunakan sebagai komponen strategi pemasaran yang aktif untuk pengembangan usaha serta sebagai keputusan terakhir konsumen untuk pemasaran.

Bekal yang harus dimiliki seorang wirausahawan adalah memiliki kemampuan dalam mengenali pasar potensial sebagai sasaran produknya, Karena bukan hal yang mudah untuk membuat masyarakat yang memiliki beranekaragam selera, gaya hidup, kondisi keuangan, lokasi tempat tinggal dan perbedaan-perbedaan lain, untuk menyukai dan membeli produk yang dihasilkan, Penelitian ini menemukan bahwa pembeli utama produk adalah anak-anak sekolah/ mahasiswa dan jangkauan pasar meliputi daerah sekitar rumah makan, Penentuan segmen pasar ini menjadi penting karena dengan hal ini maka usaha akan bisa berjalan dengan lebih efektif (tepat sasaran), efisien (hemat) dan membuat orang akan mengingat usaha ini karena spesialisasi tersebut.

Temuan penelitian mengenai kemudahan membeli adalah lokasi dari rumah makan Padang mudah terjangkau dan terdapat layanan antar, Lokasi tempat usaha menjadi 
pilihan krusial karena akan menentukan apakah bidang usaha yang dipilih dapat berkembang dengan baik atau justru akan terpuruk, Produk yang diberikan suatu bidang usaha akan banyak dikenal bahkan diminati konsumen jika lokasi usaha terletak dekat dari lingkungan mereka, Seperti pada penelitian ini bidang usaha Rumah Makan dengan target para pekerja kantor akan banyak diminati jika lokasinya dekat dengan gedung perkantoran, atau sebuah Cafe dengan konsep alam akan diminati jika terletak di tempat berpanorama indah dan berudara cukup sejuk, Penentuan lokasi bisnis ditentukan setelah pasar sasaran telah ditentukan agar efektif dan efisien.

Kemampuan usaha dari segi ketersediaan modal sangat mendukung proses pengembangan usaha, Pemilik rumah makan Padang sebagian besar setuju bahwa faktor keuangan/biaya merupakan hambatan utama untuk mengembangkan usaha, dimana bantuan modal banyak diperoleh dari bank, Sarana dan prasarana usaha merupakan faktor pendukung kegiatan usaha, terabaikannya kesiapan fasilitas atau instrumen dalam mendukung suatu usaha berupa modal, alat-alat produksi, lingkungan yang kondusif akan menghambat aspek produksi dan menurunkan daya saing termasuk kinerja para karyawan atau dengan kata lain menjadi faktor penting dan berpengaruh besar dalam mencapai sasaran atau tujuan dari usaha.

\section{Kewirausahaan terhadap Kinerja Usaha}

Kewirausahaan ternyata mempunyai pengaruh terhadap kinerja usaha, Hal ini menunjukkan bahwa kinerja yang akan dapat ditingkatkan oleh kewirausahaan yang baik, Prinsip-prinsip kewirausahaan yakni visi yang tajam, perencanaan yang matang, memiliki motivasi yang baik, memiliki ide-ide untuk menciptakan peluang dengan percaya diri, berani mengambil resiko.

Temuan dari analisis hasil penelitian mengenai pengaruh terhadap variabel kewirausahaan terhadap kinerja usaha, dapat diuraikan sebagai berikut: Kewirausahaan berpengaruh signifikan terhadap kinerja usaha, Kewirausaahan dilihat dari segi perencanaan mempunyai dampak terhadap kinerja usaha untuk masa depan, Hal ini dibuktikan dari hasil penelitian bahwa masyarakat Minangkabau selalu memiliki perencanaan penjualan tahun berikutnya dan membuat rencana setelah mengevaluasi yang mendalam atas masalahmasalah dan kesempatan yang ada, oleh karena itu kewirausahaan dari segi perencanaan sangat diperlukan untuk kelangsungan proses usaha, Semangat seorang wirausaha yang dapat menyesuaikan usaha terhadap situasi yang terus berubah-ubah karena mereka selalu memiliki perencanaan dalam menjalankan usahanya, Untuk usaha rumah makan, perencanaan yang matang mutlak diperlukan, tanpa perencanaan yang baik mungkin kondisi tertentu akan sulit dihindari, Membuka usaha rumah makan harus ada target yang hendak dicapai, strategi apa yang akan diterapkan, bagaimana mengantisipasi kemungkinan hambatan yang muncul secara tiba-tiba, serta cara atau strategi untuk mengatasinya, Rencana sebenarnya ibarat sebuah peta yang menunjukkan jalan-jalan yang akan dilalui dan gambaran secara keseluruhan lika-liku yang dihadapi, dengan demikian perencanaan yang matang merupakan tuntunan mencapai sasaran yang diharapkan dari usaha yang dilakukan.

Kewirausahaan dilihat dari segi motivasi diperlukan untuk pencapaian tujuan usaha, Seperti hasil yang ditemukan pada penelitian ini, pemilik Rumah Makan padang menyatakan bahwa mereka selalu belajar dari pengalaman baik dan kegagalan maupun keberhasilan, Hasil penelitian mendukung ungkapan yang di katakan oleh Usaha yang sukses dan mampu bertahan lama, akan banyak dipengaruhi oleh motivasi yang dimiliki pimpinan wirausaha, oleh karenanya, untuk menjadi wirausahawan yang berhasil diperlukan seseorang yang berbakat dan mempunyai motivasi untuk menciptakan sesuatu yang baru sesuai 
dengan keinginan, Motivasi merupakan semangat dan wawasan yang akan membuat seseorang bekerja keras untuk melakukan pembentukan ide atau gagasan baru, sehingga akan membuat kinerja usaha menjadi lebih menguntungkan dengan meningkatnya semangat untuk mengembangkan usaha.

Kewirausahaan dilihat dari segi peluang diperlukan untuk keuntungan usaha di masa yang akan datang, Temuan dari penelitian ini adalah pemilik Rumah Makan padang selalu mencari informasi peluang usaha untuk dapat dikembangkan, Peluang atau kesempatan tidak datang berulang tapi hanya sekali dalam waktu yang singkat, oleh karena itu perlu diadakan antisipasi dan waktu yang tepat untuk melihat berbagai peluang yang ada dan mengukur serta memperkirakan setiap peluang yang timbul, Seperti yang dapat dilihat, yaitu banyak kasus bisnis membuktikan antisipasi yang ada dapat membawa kesuksesan dalam usaha, misalnya peluang pertumbuhan potensi laba, Pendirian suatu usaha harus diimbangi dengan sikap atau perilaku untuk berhati-hati mengevaluasi peluang sebelum memilih pasar dan sasaran.

Kewirausahaan dilihat dari segi percaya diri yang berkaitan dengan sikap seorang pemimpin atau pemilik usaha diperlukan agar dapat mengembangkan usaha, Sikap kepercayaan diri seorang pemilik, berdasarkan temuan penelitian bahwa mereka menerapkan kiat-kiat khusus untuk bersaing dan sukses dalam berusaha, Setiap pemilik usaha dituntut untuk tanggap dan beradaptasi terhadap perubahan dari waktu ke waktu agar bisnis yang dijalankan dapat terus hidup, tumbuh, dan berkembang, serta memenangkan persaingan dalam kegiatan usaha, Sifat kepercayaan diri pada wirausahawan menentukan jalannya kinerja usaha, hal ini dikarenakan jika seorang wirausahawan memiliki kepribadian yang mantap, tidak mudah terpengaruh oleh pendapat orang lain, memiliki optimisme tinggi atas keputusan yang diambilnya, maka orang tersebut akan mampu meng- arahkan usahanya sendiri sesuai inisiatif atas ilmu pengetahuan yang dimiliki.

Kewirausahaan dilihat dari segi pengambilan resiko diperlukan Wirausahawan tidak takut menjalani pekerjaan dengan resiko besar selama mereka telah memperhitungkannya akan berhasil mengatasi resiko itu, Mereka menyadari bahwa prestasi besar hanya mungkin dicapai jika mereka bersedia menerima resiko sebagai konsekuensi terwujudnya tujuan untuk memperoleh penjualan yang tinggi, Wirausahawan tidak takut menjalani pekerjaan dengan resiko besar selama mereka telah memperhitungkannya akan berhasil mengatasi resiko itu, Mereka menyadari bahwa prestasi besar hanya mungkin dicapai jika mereka bersedia menerima resiko sebagai konsekuensi terwujudnya tujuan untuk memperoleh penjualan yang tinggi, Temuan penelitian menunjukkan bahwa pemilik rumah makan Padang sering mencoba cara kerja yang baru dan sering mencoba cara penjualan yang baru serta berani mengambil resiko setelah melihat kemungkinan sukses akibat keputusan yang diambil secara sistematik dan menyeluruh dengan berbagai perhitungan yang mungkin dilakukan.

Kewirausahaan dilihat dari segi adaptasi diperlukan proses penyesuaian diri terhadap perkembangan yang ada, Berdasarkan hasil observasi terhadap pemilik rumah makan Padang, diketahui bahwa mereka melayani berbagai macam keinginan pembeli yang berbeda-beda dan selalu mempertahankan resep lama warisan keluarga yang menjadikan ciri khas dari Rumah Makan tersebut, dan mereka juga melakukan penyesuaian-penyesuaian.

Ke mana pun mereka merantau, di mana pun mereka berada, orang Minang memiliki daya adaptasi yang tinggi dengan lingkungannya, Ini sesuai dengan ungkapan yang merupakan pedoman hidup mereka: di mana bumi di pijak, di situ langit dijunjung, Atau, di kandang kambing mengembek, di kandang kerbau mengo'ek, Karena daya adaptasi, kemampuan menyesuaikan diri, yang tinggi itu, mereka pun diterima oleh masyarakat di 
mana mereka berada, Berkaitan dengan hal tersebut, pemilik rumah makan Padang yang berasal dari suku Minangkabau selalu memiliki informasi yang berkembang dan selalu berubah sebagai upaya untuk beradaptasi terhadap lingkungan.

Dari hasil di atas, responden mendiskripsikan Kinerja usaha Rumah makan Padang dinilai tinggi ini menujukan responden telah merasa bahwa kinerjanya selama ini sudah dinilai baik ini ditunjukan dengan pertumbuhan penjualan relatif meningkat begitu juga laba bersih pertahun rumah makan relatif ikut meningkat.

\section{SIMPULAN DAN SARAN Simpulan}

Secara global dari hasil penelitian ini dapat ditarik kesimpulan budaya minangkabau mempengaruhi kewirausahaan pemilik usaha tidak mempengaruhi kemampuan usaha akan tetapi dapat pula meningkatkan kinerja usaha, Adapun pengaruh masing-masing variabel dalam penelitian ini dapat diuraikan sebagai berikut: (1) Budaya Minangkabau berpengaruh signifikan terhadap kewirausahaan, Dengan demikian hipotesis yang diajukan pada Budaya Minangkabau mempunyai pengaruh langsung terhadap Kewirausahaan Pemilik Rumah Makan Padang terbukti; (2) Budaya Minangkabau berpengaruh signifikan terhadap kemampuan usaha, Budaya Minang berpengaruh terhadap peningkatan kemampuan usaha, Kemampuan usaha disini dalam artian kemampuan (Capabilities) mengacu pada ketrampilan (skill) perusahaan dalam mengkoordinasikan sumber daya dan menempatkannya untuk penggunaan secara produktif, Dengan demikian hipotesis yang diajukan pada Budaya Minangkabau mempunyai pengaruh langsung terhadap kemampuan usaha Rumah Makan Padang terbukti; (3) Budaya Minangkabau berpengaruh signifikan terhadap kinerja usaha Dengan demikian hipotesis yang diajukan pada Budaya Minangkabau mempunyai pengaruh langsung terhadap kinerja usaha Rumah Makan Padang terbukti; (4) Ke- wirausahaan berpengaruh tidak signifikan terhadap kemampuan usaha Unsur budaya menunjang dalam meningkatkan produktivitas, dalam artian budaya dapat menunjang kemampuan yang dimiliki seseorang sebagai satu faktor penting dalam meningkatkan kinerja Dengan demikian hipotesis yang diajukan pada Kewirausahaan Pemilik Rumah Makan Padang mempunyai pengaruh langsung terhadap kinerja usaha Rumah Makan Padang terbukti; (5) Kewirausahaan berpengaruh signifikan terhadap kinerja usaha, Dengan demikian hipotesis yang diajukan pada kewirausahaan mempunyai pengaruh langsung terhadap kinerja usaha Rumah Makan Padang terbukti.

Penelitian ini menghasilkan temuan penting sebagai berikut: (1) Potensi kepribadian wirausaha, pengetahuan wirausaha dan lingkungan keluarga berpengaruh positif dan signifikan terhadap minat wirausaha; (2) Kewirausahaan berpengaruh signifikan terhadap kemampuan usaha dan keberhasilan usaha; (3) Terdapat perbedaan dari hasil penelitian terdahulu dari Welsa (2009) terutama pada indikator merantau yang tidak signifikan; (4) Penemuan dari studi ini secara empirik penting bagi pengembangan teori dan praktek kewirausahaan di Indonesia.

\section{DAFTAR PUSTAKA}

Adam, J. D. 2005. Migrant and Local Entrepreneurial Networks Development. Jurnal Manajemen dan Kewirausahaan 6(2): 93-104.

Alfianto, E. A. 2012. Kewirusahaan Sebuah Kajian Pengabdian Kepada Masyarakat. Journal Heritage 1(2): 33-42).

Andiningtyas R. S. I dan R. L. Nugroho. 2014. Pengaruh Orientasi Kewirausahaan terhadap Kinerja Perusahaan Kecil. Jurnal Manajemen Indonesia 14 (1): 1-19.

Aprilianty, E. 2013. Pengaruh Kepribadian Wirausaha, Pengetahuan Kewirausahaan, dan Lingkungan terhadap Minat Berwirausaha Siswa SMK. Jurnal Pendidikan Vokasi 2(3): 311-324. 
Dalimunthe, R. F. 2002. Pengaruh Karakteristik Individu, Kewirausahaan, Gaya Kepemimpinan Terhadap Kemampuan Usaha serta Keberhasilan Usaha Industri Kecil Tenun dan Bordir di Sumatra utara, Sumatera Barat dan Riau. Disertasi. Universitas Airlangga. Surabaya (tidak dipublikasikan).

Darwis, R. 2004. Tranformasi Nilai-nilai Tradisi Kekeluargaan Masyarakat Minangkabau dalam Pendidikan Kewiraswastaan. Cetakan Kedua. Pustaka Aulia Press. Bandung.

Fauzan. 2011. Pengaruh Religiusitas terhadap Etika Berbisnis (Studi pada RM. Padang di Kota Malang). Jurnal Manajemen dan Kewirausahaan 15(1): 53-64.

Fithri, P. dan A. F. Sari. 2012. Analisis Kompetensi Kewirausahaan Industri Kecil Suku Cadang di Kota Padang. Jurnal Optimasi Sistem Industri 11(2): 279292.

Hadiyati, E. 2011. Kreativitas dan Inovasi Berpengaruh Terhadap Kewirausahaan Usaha Kecil. Jurnal Manajemen dan Kewirausahaan 13(1): 8-16.

Koentjaraningrat. 1990. Pengantar Ilmu Antropologi. Cetakan Kedelapan. Penerbit PT. Rineka Cipta. Jakarta.

Kumalaningrum, M. P. 2012. Lingkungan Bisnis, Orientasi Kewirausahaan, Orientasi Pasar dan Kinerja Usaha Mikro, Kecil dan Menengah. JRMB 7(1): 45-59.

Lestari, R. B. dan Megawati. 2015. Analisis Pengaruh Kualitas Kewirausahaan terhadap Kinerja Usaha Kecil dan Menengah (Studi Empiris pada Industri Kerupuk Kemplang di Palembang). Journal of Small Business Management LPPM STIE MPD 6(1): 1-6.

Lestari, R. B. dan T. Wijaya. 2012. Pengaruh Pendidikan Kewirausahaan terhadap Minat Berwirausaha Mahasiswa STIE MDP, STMIK MDP, DAN STIE MUSI. Forum Bisnis dan Kewirausahaan Jurnal Ilmiah STIE MDP 1(2): 112-119.

Lukas, S. 2004. Peran Orang Tionghoa dalam Perdagangan dan Hidup Perekonomian dalam Masyarakat (Studi Kepustakaan dan Studi Kasus tentang Interaksi Etnik Tionghoa dan Pribumi di Bidang Perekonomian di Surabaya). Jurnal Manajemen dan Kewirausahaan 5(2): 193-206.

Naim, M. 1979. Merantau, Pola Migrasi Suku Minangkabau. Gajah Mada University Press. Yogyakarta.

Nurseto, T. 2004. Strategi Menumbuhkan Wirausaha Kecil Menengah yang Tangguh. Jurnal Ekonomi dan Pendidikan 1(1): 96-105.

Purhantara, W. 2013. Analisis Kepemilikan Jiwa Kewirausahaan:Evaluasi Outcome Pendidikan Menengah di Jawa. Jurnal Economia 9(2): 175-190.

Purnama, C. 2011. Motivasi dan Kemampuan Usaha dalam Meningkatkan Keberhasilan Usaha Industri Kecil (Studi pada Industri Kecil Sepatu di Jawa Timur). Jurnal Manajemen dan Kewirausahaan 12(2): 177-184.

Rante, Y. 2010. Pengaruh Budaya Etnis dan Perilaku Kewirausahaan Terhadap Kinerja Usaha Mikro Kecil Agribisnis di Provinsi Papua. Jurnal Manajemen dan Kewirausahaan 12(2): 133-141.

Reswanda. 2011. Pengaruh Orientasi Kewirausahaan terhadap Pembelajaran Organisasi, Keunggulan Daya Saing Berkelanjutan dan Kinerja Usaha pada UMKM Kerajinan Kulit Berorientasi Ekspor di Sidoarjo. Disertasi. Universitas Airlangga. Surabaya.

Sabri. 2013. Kewirausahaan (Entrepreneurship): Modal Manusia dalam Membangun Perekonomian. Jurnal Ekonomika Universitas Almuslim Bireuen Aceh 4(7): 26-32.

Setiawan, H. 2013. Pengaruh Orientasi Pasar, Budaya Organisasi dan Orientasi Kewirausahaan terhadap Kinerja Usaha (Studi pada Usaha Kecil Pengolahan di Kota Palembang). Jurnal Manajemen dan Bisnis Sriwijaya 11(3): 181-194.

Setyawati, H. A. 2013. Pengaruh Orientasi Kewirausahaan dan Orientasi Pasar terhadap Kinerja Perusahaan Melalui Keunggulan Bersaing dan Persepsi Ketidakpastian Lingkungan Sebagai 
Prediksi Variabel Moderasi (Survey pada UMKM Perdagangan di Kabupaten Kebumen). Journal STIE Putra Bangsa 12(2): 20-31.

Suci, R. P. 2009. Peningkatan Kinerja Melalui Kewirausahaan, Kemampuan Manajemen, Strategi Bisnis (Studi Kasus pada Industri Menengah Bordir di Jawa Timur). Jurnal Manajemen dan Kewirausahaan 11(1): 46-58.

Suharti, L. dan H. Sirine. 2011. Faktor-faktor yang Berpengaruh terhadap Niat Kewirausahaan (Entrepreneurial Intention) (Studi terhadap Mahasiswa Universitas Kristen Satya Wacana Salatiga). Jurnal Manajemen dan Kewirausahaan 13(2): 124-134.

Sultan. 2015. Pengaruh Kompetensi Wirausaha terhadap Strategi, Kinerja Bisnis dan Daya Saing Usaha Kecil di Sulawesi Selatan. Jurnal Ilmiah Bisnis dan Kewirausahaan 4(4): 1-6.
Sumantri, B., A. Fariyanti., dan R. Winandi. 2013. Faktor-faktor yang Berpengaruh terhadap Kinerja Usaha Wirausaha Wanita: Suatu Studi pada Industri Pangan Rumahan di Bogor. Jurnal Manajemen Teknologi 12(3): 252-277.

Welsa, H. 2009. Pengaruh Kewirausahaan terhadap Kemampuan Usaha serta Kinerja Usaha Rumah Makan Padang di Yogyakarta. Jurnal Ekonomi dan Keuangan EKUITAS 13(3): 371-387.

Wijaya, T. 2008. Kajian Model Empiris Perilaku Berwirausaha UKM DIY dan Jawa Tengah. Jurnal Manajemen dan Kewirausahaan 19(2): 93-104. 